\title{
Approaching compost stability from Klason lignin modified method: Chemical Stability Degree for OM and $N$ quality assessment
}

Marga López*; Oscar Huerta-Pujol; F. Xavier Martínez-Farré; Montserrat Soliva

Department of Agri-Food Engineering and Biotechnology (DEAB)

Escola Superior d'Agricultura de Barcelona.

Universitat Politècnica de Catalunya (UPC).

c/ Esteve Terradas, 8.

08860 Castelldefels, Spain.

*Corresponding author:

Department of Agri-Food Engineering and Biotechnology (DEAB)

Escola Superior d'Agricultura de Barcelona.

Universitat Politècnica de Catalunya (UPC).

c/ Esteve Terradas, 8.

08860 Castelldefels, Spain.

E-mail: marga.lopez@upc.edu

Telephone: +34935521098

Fax: +34935521001 


\begin{abstract}
Compost stability and maturity can be assessed by many methods, differing in both sample preparation and produced information. The method proposed here is the chemical Stability Degree (SD) the origin of which can be related to the Klason method for lignin determination in wood and pulp. It allows determination of the stability of organic matter and nitrogen through Resistant Organic Matter and Non Hydrolysable Nitrogen determinations, in any kind of dry and ground sample. This method avoids the disadvantages related to the determinations conducted on wet sample, such as respirometries or self heating test, which are effected by the water content and the particle size. The SD has been applied to different raw organic materials as well as to composts of different origin, producing reliable results. The Pearson correlations of SD with other usual parameters that can inform on compost quality have been of interest, revealing its usefulness to determine compost stability.
\end{abstract}

\title{
Keywords
}

Klason; composting; stability; maturity; lignin; resistant organic mater

\section{Introduction}

Sustainable soil management is possible only if soil organic matter is maintained above certain critical levels; this is a key task in soil management and in many systems is only possible by importing organic matter from exogenous organic materials (EOM) of suitable quality. The addition of EOM can limit the decline of soil organic matter and reduce erosion. If the EOM has been previously treated (composted) it will decompose more slowly than fresh materials and will improve the soil characteristics and, consequently many of its functions, as well as increase food and biomass production and contribute to carbon sequestration. All these advantages depend on the organic matter stability and are strongly related to a well controlled composting process. There is a good interaction between soil management, optimisation of waste management and carbon sequestration (Smith 2004; Favoino and Hogg, 2008; Adani et al., 2009); the compost stability, together with other characteristics, is basic for the achievement of this interaction and for the maximisation of soil carbon fixation and thus reduction of the emission of carbon dioxide to the atmosphere.

Compost stability and maturity are terms usually employed indistinctly and are generally not regulated as qualification indices. Compost stability refers to a specific stage of decomposition during composting, which is related to the types of organic compounds remaining and the resultant biological activity that can be measured by respiration rates (Cooperband et al., 2003; Tognetti et al., 2007). Compost maturity is related to its suitability in final use for compost and crop growing, although some authors also relate it to humification (Tomati et al., 2000). It is true that if composting has been adequately controlled the final product will be stable but could involve certain phytoxicity problems for the crops due to, for example, high electric conductivity of the feed materials that will affect the maturity concept. Biocycle's Editor (1999) distinguished stability as a condition of the material, and maturity as a quality.

It seems difficult to clearly distinguish between both terms. It is also unlikely that one single parameter can definitely assess stability or maturity, mainly because of the wide variety of composting feedstocks, management practices and compost end uses. More information about other characteristics would be necessary in order to describe the composting process, understand the results and to forecast the behaviour of a compost application.

Lately there has been special concern about the determination of the stability in mechanical-biologically treated product and the establishment of a proof as a respiration test to determine its behaviour at the landfill (Adani and Ricca, 2004; Wagland et al., 2009). The need for other parameters to understand and interpret the changes of the material during the biological treatment must be kept in mind.

Stability degree (SD) is related to Klason method of lignin content determination (Klason, 1908; 1910), which has been enhanced and applied by several authors (Busche, 1960; Sjöström and Alén, 1999; NREL, 2002). It was also used by Belgium Agriculture Ministry in 1971 to characterise peat (Ministère de l'Agriculture de Belgique, 1971) showing good lineal ratio with the Von Post scale, which fits with the morphologic peat ranking (from 1 to 10) according to decomposition rate.

$$
\mathrm{SD}=6.1 * \mathrm{H}_{\text {von Post }}+20.5 \quad \text { (von Post 1924) }
$$


It can also be related to the determination of fibre content in feedstock (Van Soest and Wine, 1967) which has been used by different authors to characterise composts and like-products (Higgins et al., 1982; Binner and Zach, 1999; Hutchinson and Griffin, 2008; Morvan and Nicolardot, 2009). Authors such as Inoko et al. (1979) demonstrated that the SD showed the evolution degree of organic fraction of MSW during composting. Adani et al. (1995) developed a new organic matter stabilisation index using a separation method by dividing the labile and recalcitrant OM fractions of compost using a procedure similar to Klason lignin isolation. Also, the chemical partition of compost organic matter into recalcitrant and labile pools has been shown to correspond to the carbon retained and degraded after soil incubation (Rovira and Vallejo, 2002; Adani and Ricca, 2004).

Stability degree has been used in parallel with other general determinations (Saña et al., 1989) and other more specific ones such as respirometric techniques (More and Saña, 1987; Saña et al., 1989) or self-heating test (López, 2010). Earlier determinations were applied to sewage sludge characterisation (Saña, 1985), in the study of MSW compost (Moré and Saña, 1987; Saña et al., 1989) and other organic waste. Later, the method was improved and used in different works (López et al., 2010a, 2010b).

Apart from the changes in the basic SD methodology, the original method has been improved and expanded by the addition of the resistant nitrogen determination $(\mathrm{Nr})$. The $\mathrm{N}$ supply with compost has only a minor significance for the fertilisation because the organically bound nitrogen mobilises at very low rates (Sullivan et al., 2003). The organic $N$ in the compost can be in various forms mainly due to different degradative and condensation reactions involved in the co-composting materials rich in lignin and polysaccharides with nitrogenous compounds (Tuomela et al., 2000); as a part of SD method the more resistant N can be measured. This is very important in order to prevent unexpected $\mathrm{N}$-mobilisation events and leaching into the groundwater, when the EOM is applied and, at the same time, to decide whether there is a need for mineral supply.

In this paper the following issues will be discussed:

- the suitability of chemical stability degree by sulphuric acid (SD) to evaluate stability of organic materials and compost samples according to their origin

- $\quad$ the relation of SD with other parameters to assess its effectiveness as stability parameter

- the agronomic interpretation and utility of these results in order to predict the behaviour of the material in application.

\section{Materials}

Different organic materials and compost from municipal solid waste were analysed for general characteristics and for Stability Degree (SD) and resistant nitrogen (Nr). All organic materials selected (table 1) were analysed in order to assess the suitability of the method as well as to obtain information on their stability. Different groups have been studied:

- Group I: different organic raw materials that can either be used in composting process and/or directly applied to land

- Group II : municipal solid waste compost samples

As there is little information about how the initial waste mixture has an influence on the kinetics of organic matter evolution during composting, group II was divided into 3 groups:

MS 1: 49 samples were obtained from existing facilities in Catalonia (NE Spain) before separate collection of MSW was established (1997), where the only difference was the technology used in the plants. The incoming material consisted of municipal solid waste without previous selection, so before composting mechanical sorting of the organic fraction was carried out in the facilities.

MS 2: 48 samples of municipal solid waste without previous selection of organic fraction were taken after 1997 when policies of separated collection for plastic, glass and paper began. Moreover, the separate collection by citizens in street banks contributed to the reduction in the amount of non composting materials arriving at biological treatment plants. The technology applied in these facilities was far better than that used in former composting plants (MS1). 
SC: Because of the law 6/93 on wastes, from 1997, municipalities in Catalonia of more than 5,000 inhabitants were forced to separately collect the organic fraction to be treated through composting or anaerobic digestion. Due to the characteristics of this cleaner and wetter organic fraction (López et al., 2010a), it was established that the best partner to compost it was the yard trimmings (López et al., 2010b), in order to absorb extra water, contribute as a carbon source and maintain a suitable structure to provide oxygen. These mixtures have been treated in facilities with different capacity and varied technologies. This group consists of 167 samples.

To analyse results and compare SD with other parameters, the SC group has been split into 3 sub-groups depending on SD results matching other recognised parameters related to stability, such as ammonium content.

Table 1 Groups of studied samples

\begin{tabular}{llll}
\hline Group & Material & Years & Specific features \\
\hline I & Organic materials & 2003-2007 & Not composted \\
\hline MS1 & Before 1997 & $\begin{array}{l}\text { MSW without any previous selection of materials. } \\
\text { OF sorted in the facility. } \\
\text { Different facilities and treatment technologies. }\end{array}$ \\
\hline II & 2003-2005 & $\begin{array}{l}\text { MSW with some previous source selection of glass, paper, } \\
\text { plastic. }\end{array}$ \\
& & $\begin{array}{l}\text { OF sorted in the facility. } \\
\text { Different facilities with different capacities and } \\
\text { technologies } \\
\text { Improved technologies from MS1. }\end{array}$ \\
MSW Compost & $\begin{array}{l}\text { OF source separated in origin. } \\
\text { Co-composting of OF with yard trimmings. } \\
\text { Different facilities with different capacities and } \\
\text { technologies. }\end{array}$ \\
\cline { 2 - 3 } & & \\
SC & 2003-2005 from source & & \\
separated Compost & &
\end{tabular}

\section{Methods}

The main method explained here is the stability degree of organic matter by means of sulphuric acid but, for a proper interpretation of the results of analysed materials, complementary determinations (total organic matter and organic nitrogen) are needed and the stability degree has to be contrasted with the general characterisation. One single parameter cannot assess quality or behaviour by itself.

\subsection{General characterisation}

The sampling and general characterisation was carried out according to Saña et al. (1989) and López et al. (2010a, 2010b). When the samples arrived at the laboratory each one was again mixed for homogenisation and split into two parts; one for analysis conducted in the wet sample $\left(\mathrm{pH}, \mathrm{EC}, \mathrm{MC}\right.$ and $\left.\mathrm{NH}_{4}{ }^{+}-\mathrm{N}\right)$ and the other for analysis in the dry sample. Each analysis was performed twice and the differences between each were always less than $5 \%$.

Determinations on wet sample. Moisture content (MC) was determined by drying in a heater at $110^{\circ} \mathrm{C}$ until constant weight was achieved. $\mathrm{pH}$, electric conductivity (EC) and water soluble inorganic nitrogen $\left(\mathrm{NH}_{4}{ }^{+}-\right.$ $\mathrm{N})$, were determined in distilled water extract $1 / 5(\mathrm{w} / \mathrm{v})$ using specific electrodes.

Determinations on dry and ground sample. Total organic matter (\%TOM) was determined by loss on ignition at $560^{\circ} \mathrm{C}$. Organic nitrogen (\%orgN) was determined by specific ion electrode after Kjeldahl digestion.

It must be pointed out that the SD determination was also conducted on a dry and ground sample which provided better repeatability than fresh sample determinations; when fresh samples cannot be processed immediately and require storage (refrigeration and/or freezing) some aspects relating to maturity/stability can be affected (Wu and Ma, 2001).

\subsection{Stability degree by sulphuric acid}


The composition of organic wastes and biomass includes cellulose (b-glucose polymer), hemicellulose (complex polymer with main chain consists of xylans or glucomannans) and lignin (complex phenolic polymer). The Klason lignin method described in Standard method TAPPI T222 om-88 to determine lignin content in wood and pulp has been widely used. As long as lignin is mostly insoluble in mineral acids, it can be analysed gravimetrically after hydrolysing the cellulose and hemicelluloses fractions with sulphuric acid.

The adaptation of Klason method for the SD method allows the determination of two parameters of importance in assessing the effectiveness of certain treatment processes and for the use of compost: percentage of Resistant Organic Mater (\%ROM) and the percentage of non hydrolysable nitrogen (\%nH-N). Both parameters represent an improvement on the classic method and are important indicators of organic matter quality. So, the SD method not only determines the stability of the sample but nitrogen stability too, and hence, it can be considered a good indicator of organic waste quality rather than just as a stability indicator.

Determination of SD consists of two consecutive sulphuric hydrolysis applied to dry and ground samples. The first, in cold and concentrated sulphuric, destroys celluloses and more labile carbonaceous compounds, while the second, in hot and diluted sulphuric acid up to $0.7 \mathrm{~N}$, hydrolyses the rest of polysaccharides as well as hemicelluloses and proteins. Lignin and humic-like substances (the more resistant fraction) remain. From this resistant residue \%ROM and \%nH-N can be determined. Final value of SD and resistant nitrogen are expressed as:

$$
\% \mathrm{SD}=\frac{\% \mathrm{ROM}}{\% \mathrm{TOM}} * 100 \quad \% \mathrm{rN}=\frac{\% \mathrm{nH}-\mathrm{N}}{\% \text { org }-\mathrm{N}} * 100
$$

Figure 1 compares the differences of both proceedings, Klason and SD. It must to be pointed out that the Klason method also states that for samples with significant content of resins a previous extract must be carried out using an ethanol-benzene mixture before the first hydrolysis.

\section{Fig 1 Klason method compared to SD method}

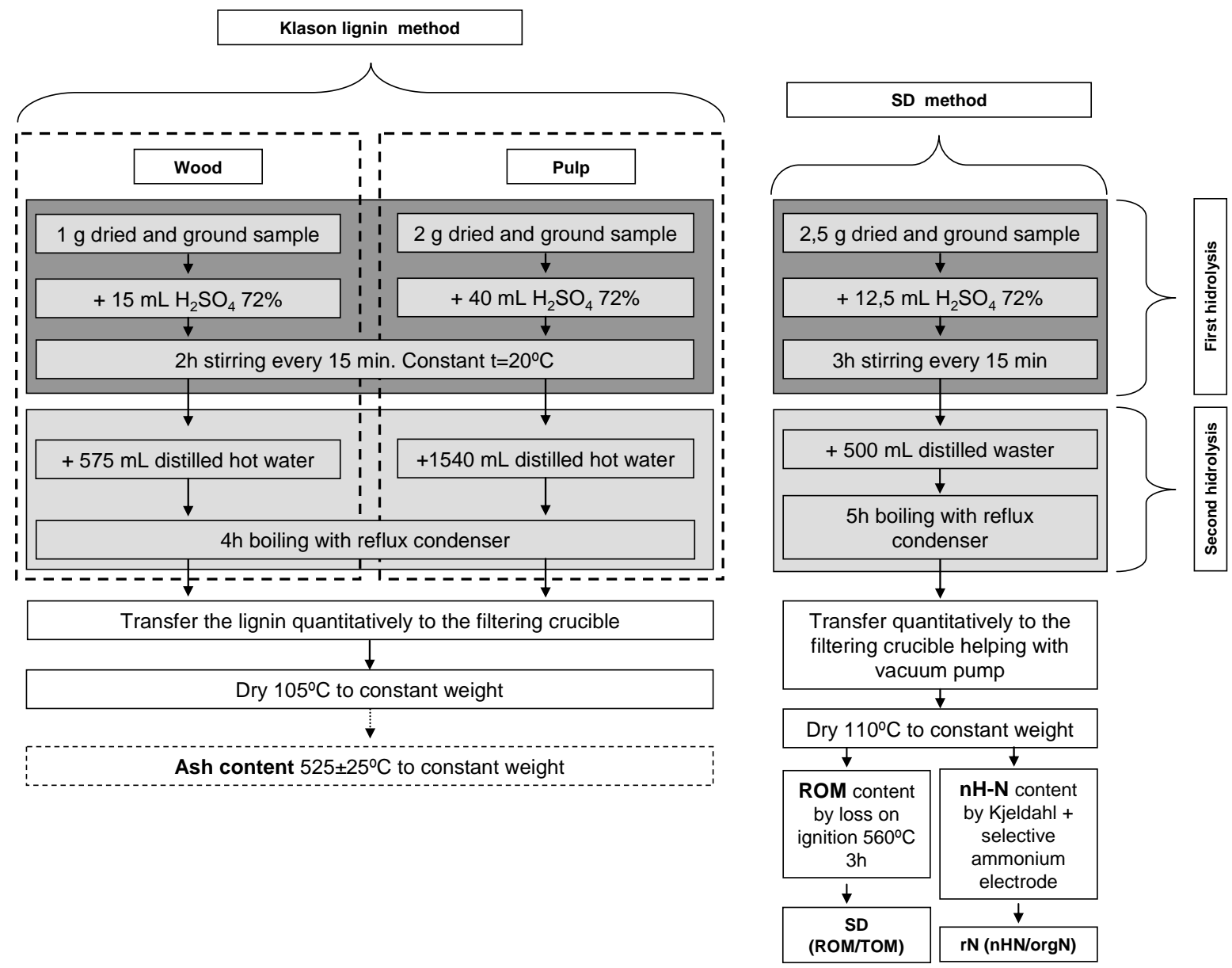


In spite of the differences, both methods are quite similar in both hydrolysis. It must be taken into account that the target samples for each method are different, being applied to wood and pulp in Klason but for all kind of organic waste in this article. The former is a gravimetric approach measuring acid insoluble material that is defined as lignin and this can be overestimated (Veeken et al., 2001); but the latter works with the acid insoluble material and guides the results towards determining organic matter and nitrogen in the residue, both highly related to the agronomic behaviour in land application of organic materials.

\section{Procedure}

- Weigh $2.5 \mathrm{~g}$ dried and ground sample, with precision of $0.1 \mathrm{mg}$, inside a $100 \mathrm{~mL}$ plastic beaker. Add $12.5 \mathrm{~mL}$ $\mathrm{H}_{2} \mathrm{SO}_{4} 72 \%$ step by step to avoid foam formation and stirring with a glass rod to mix properly. Stir every 15 minutes for 3 hours.

- Transfer the mixture to a $1 \mathrm{~L}$ ground-glass neck erlenmeyer flask joint helping with $500 \mathrm{~mL}$ distilled water and dragging the entire sample. Rub the ground glass joint with silicone, assemble erlenmeyer to reflux condenser (or heating manifold equip with a reflux condenser). Boil gently for 5 hours in an electric sand bath stirring from time to time to prevent the sample from sticking to the erlenmeyer. Allow to cool and decant the next day.

- Filter to vacuum through previously weighed Gooch filtering crucibles, into a filtering flask and recover all the solids in the crucible. Help with small amounts of distilled water. Once all the solids have been retained by the filter, it must be checked that there are no sulphates by adding some drops of $\mathrm{Ba}\left(\mathrm{NO}_{3}\right)_{2} 1 \mathrm{~N}$ in the filtered liquid. If there are sulphates a precipitate will appear; if so, add more water to the filter and try again. Dry the filters in the heater for $2-4 \mathrm{~h}$ at $110^{\circ} \mathrm{C}$ until a constant weight. Allow to cool in a dessicator and weigh.

- Homogenise the dry residue and weigh $0.4-0.5 \mathrm{~g}$ to determine nitrogen through Kjeldahl digestion for $1 \mathrm{~h}$ at $400^{\circ} \mathrm{C}$. Transfer the digest by filtering up to $100 \mathrm{~mL}$ in a flask adding distilled water. Quantification is done by potentiometry with an ammonia selective electrode.

- Transfer the rest of the residue to a blackened and weighed porcelain crucible to determine \%ROM, preblacken on hot plate and blacken in the muffle furnace for $4 \mathrm{~h}$ at $560^{\circ} \mathrm{C}$. Allow to cool in a desiccator and weigh.

- For $\mathrm{nH}-\mathrm{N}$ determination, prepare a test chart of $0,2,5,10,20,50$ and $100 \mathrm{mg} \mathrm{N} \mathrm{L}^{-1}$ in $50 \mathrm{~mL}^{-}$Nessler tubes. For samples, transfer $10 \mathrm{~mL}$ of the digest and fill with distilled water up to $50 \mathrm{~mL}$.

\subsection{Related calculated parameters}

Several related calculations can be made after SD determination and basic parameters, which can improve information about nutrient behaviour and organic matter characterisation. These are summarised as follows:

- $\quad \% \mathrm{mN}-\mathrm{oN}\left(\mathrm{NH}_{4}{ }^{+}-\mathrm{N} /\right.$ org- $\left.\mathrm{N}\right)$. Can inform about the relation between mineral and organic nitrogen.

- $\quad \% \mathrm{mN}-\mathrm{nHN}\left(\mathrm{NH}_{4}{ }^{+}-\mathrm{N} / \mathrm{nH}-\mathrm{N}\right)$. The changes in both contents can amplify the meaning of individual changes in the parameters.

- Degradable organic matter (\%DOM $=\% \mathrm{TOM}-\% \mathrm{ROM}$ ) reflects the easily mineralisable part, which could release nutrients more quickly and can contribute to environmental problems.

- Easily degradable nitrogen (\%h- $\mathrm{N}=\%$ org- $\mathrm{N}-\% \mathrm{nH}-\mathrm{N}$ ) would be involved in the release of nitrogen in the short-medium term.

\subsection{Statistical analysis}

In order to evaluate the differences in the measured parameters between groups of samples according to the type of municipal solid waste organic fraction and period of time, data for each parameter were subjected to oneway ANOVA considering the group sample as a source with 3 levels of variation: MS1, MS2 and SC. After that, least square means were compared using Tukey-Kramer test $(p<0.05)$. 
In order to evaluate the differences in the measured parameters between groups of samples according to the composting process performance focused on source collected municipal solid waste organic fraction, data for each parameter were subjected to one-way ANOVA considering the group of samples as a source with 3 levels of variation: SC1, SC2 and SC3. After that, least square means were compared using Tukey-Kramer test $(p<0.05)$.

Moreover, Pearson correlation analyses were performed in order to investigate the relationship between the Stability Degree (SD) and the rest of the parameters considered for groups of samples according to the type of municipal solid waste organic fraction and period of time (MS1, MS2 and SC).

All statistical analyses were performed using the GLM procedure (SAS Institute, Inc. 1999). Data were transformed using natural logarithm prior to the analyses. Moreover, in all cases residual analyses were performed. Means showed along the text are accompanied by standard error (mean $\pm \mathrm{se}$ ).

\section{Results and discussion}

\subsection{Interpretation}

The kinetics of organic matter stabilisation during composting depend both on the nature of the treated waste and on the composting process. There are several parameters that focus on stability or maturity of compost, the aim of which is to categorise samples based on whether certain premises are accomplished or not. Some of them can exhibit problems related to sample conservation and pre-treatment, others can be expensive or require a lot of time for the determination, while others can even give little, inaccurate or difficult to interpret information.

Many works report the increasing stability and the evolution of organic matter characteristics during composting (Bernal et al., 1998).

The use of the SD method on different organic materials (EOM) and its comparison with other parameters has allowed improvement in implementation and use.

As a strong correlation exists between the chemical and biological stability of $\mathrm{OM}$, the ratio of chemical-labile versus chemical-recalcitrant compounds is generally used to describe OM quality (Rovira and Vallejo, 2002; Mikutta et al., 2006). Biological treatments help to increase stability due to the relative increase of resistant compounds to hydrolysis such as lignin caused by the mineralisation of labile carbonaceous compounds, and to the microbial synthesis of resistant biomolecules (humic-like substances). SD gives information on the stability of raw materials and, in the case of materials that have undergone biological treatment, can be used to assess how the process has developed. More than this, SD results give information about the behaviour of both organic matter and nitrogen in long-term soil application because they assess the resistance to degradationmineralisation.

From trials carried out in two different commercial composting plants with accurate process monitoring through the control of parameters such as $\mathrm{pH}, \mathrm{EC}, \mathrm{MC}, \mathrm{NH}_{4}{ }^{+} \mathrm{N}$, TOM, org- $\mathrm{N}$, self heating test and mainly $\mathrm{SD}$ and $\mathrm{rN}$, it is suggested that a value of $50 \%$ (Fig 2) for these last two parameters should categorise the samples as stable. Considering this value of $50 \%$ as an adequate result, a maximum of half of both will degrade in the shortmedium term once applied to soil, while the other half will do so in the long-term.

From the point of view of organic matter, it must be taken into account that compost is an organic amendment and not a fertilizer, and the aim of using this is to provide stable OM to soil. In this case, the SD method can help to predict the accumulation of OM over time. Compost efficiency to increase soil organic matter will depend both on the amount of organic matter applied and on its stability.

From the point of view of nitrogen, the more resistant it is the more slowly it will be released, preventing soil, water and air pollution and providing a medium to long-term nitrogen supply for plants, as needed. On the other hand, it would mean that during the composting process nitrogen has been properly fixed in carbonaceous compounds (Giovannozi, 1987; Hammouda and Adams, 1987; López et al., 2010b). 


\section{Fig 2 Variation in TOM, SD and rN contents in MSW composting (left) and OFMSW+YT co-} composting (right)

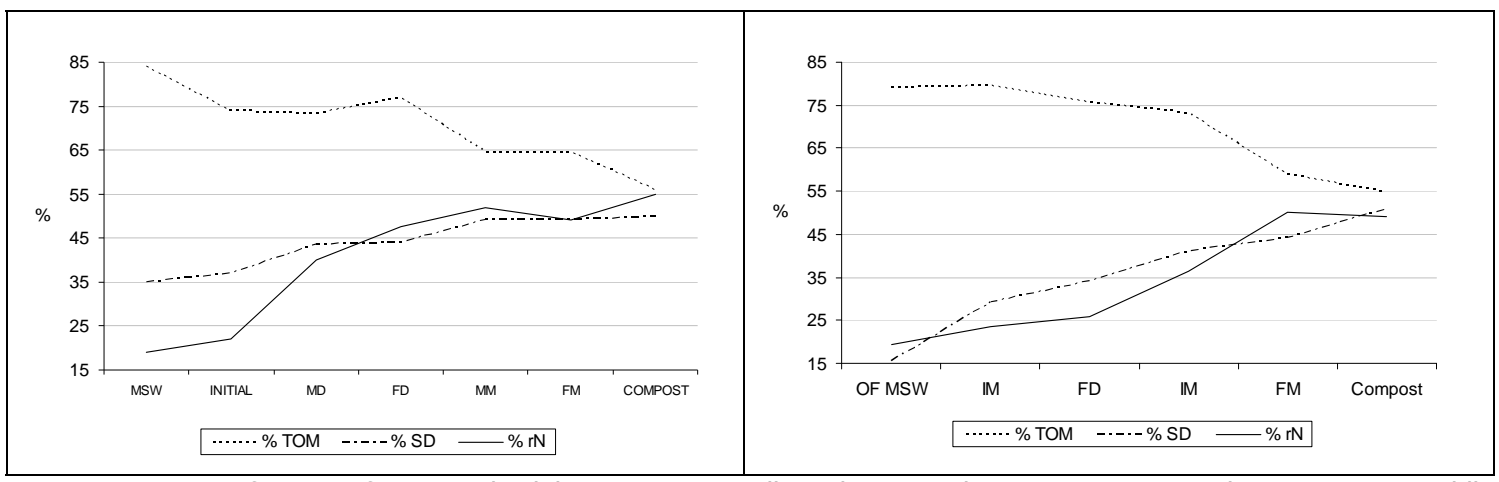

OF MSW: organic fraction of municipal solid waste source collected; YT: yard trimmings; IM: initial mixture; MD: middle decomposition; FD: final decomposition; IM: initial maturation; MM: middle maturation; FM: final maturation.

The ROM increase could be interpreted as a simple relative accumulation of lignin content but if the amount of org- $\mathrm{N}$ is increased in this organic matter fraction (understood as $\mathrm{nH}-\mathrm{N}$ ), it would mean that the lignin fraction was substantially modified and important changes to the degree of oxidation and condensation involving nitrogenous compounds would have occurred (Tuomela at al., 2000) as well as the formation of heterocyclic molecules.

\subsection{Different organic raw materials}

Table 2 summarises some characteristics of organic raw materials, whether pre-treated or not. It is necessary to observe the general characteristics and to relate them to the material origin and its presumable bio molecular composition, to properly interpret the SD and $\mathrm{Nr}$ values.

The variability of $\mathrm{pH}$ values is related to the material origin and pre-treatment; OF shows the lowest value and the cow manure the highest. The EC present a very high variability strongly related to origin and with two measured parameters: moisture and $\mathrm{NH}_{4}{ }^{+}-\mathrm{N}$ content. The variability of the moisture content depends on the origin and treatment of the samples and is a factor in sample conservation as well as purpose and treatment.

The highest $\mathrm{NH}_{4}{ }^{+}-\mathrm{N}$ values are shown for meat processing waste, followed by sewage sludge (except thermally treated) and digestate samples, while the lowest values are shown for plant origin or thermally treated samples; these values are strongly connected to the kind of material, the level of $\mathrm{N}$ and $\mathrm{C} / \mathrm{N}$, and pre-treatment. These results are of interest for better utilisation for both agronomic use of the organic waste and biological treatment; composting materials rich in nitrogen need usage and adequate complementary material to reduce $\mathrm{N}$-losses. Also, the level of nitrogen, mainly in the $\mathrm{NH}_{4}{ }^{+}-\mathrm{N}$ form, needs to be controlled in anaerobic digestion to avoid problems with the performance of the process (Lay et al., 1997).

Organic matter levels are high in all samples except for those that have undergone anaerobic treatment (DA OF) and some previously processed sewage sludge. But to conceive a proper destination for these materials it is important to know that the level of degradable OM (\%TOM-\%ROM) is high except for coffee $\mathrm{W}$, pine bark and cow hair.

The parameter of SD discussed in this article, as stability indicator, is very variable in the samples shown in table 2 (from $15.37 \%$ for beer industry SS, to $63.00 \%$ for cow hair) with a mean of $34.99 \%$. The low values of OF (SC and MS) can be emphasised and compared with the levels reached when those materials are biologically treated (digested, D FO in table 2 and composted in table 3 and fig 3). The parameter SD complemented with the value of org- $\mathrm{N}$ informs about the behaviour of the materials once treated, applied or land filled. The org- $\mathrm{N}$ values range from $0.30 \%$ for a lignified material such as pine bark, to $9.04 \%$ for beer industry SS, or to $14.60 \%$ for treated cow hair. The levels of resistant organic nitrogen are low except for the cow hair sample, the change for this material being noticeable when it has been treated; however the ratio \% $\mathrm{rN}(\mathrm{nH}-\mathrm{N} / \mathrm{org}-\mathrm{N})$ more clearly expresses the differences between the samples and their connexion with the future $\mathrm{N}$ behaviour. 
Table 2 General characteristics and SD and Nr parameters for organic raw materials

\begin{tabular}{|c|c|c|c|c|c|c|c|c|c|c|c|}
\hline & pH & $\begin{array}{c}\text { EC } \\
\text { dS } \mathbf{m}^{-1}\end{array}$ & $\%$ MC & $\begin{array}{l}\text { Soluble } \\
\mathrm{N}-\mathrm{NH}_{4}{ }^{+} \\
\mathrm{mg} \mathrm{kg}^{-1}\end{array}$ & $\%$ TOM & $\%$ org-N & $\mathrm{C} / \mathrm{N}$ & \% ROM & \% SD & $\% \mathrm{nH}-\mathrm{N}$ & $\% \mathrm{rN}$ \\
\hline Coffee W & 5.70 & 0.37 & 57.83 & 96 & 99.42 & 2.47 & 20 & 55.53 & 55.86 & 1.88 & 75.80 \\
\hline Tobacco W & 5.46 & 14.99 & 11.38 & 1061 & 79.91 & 2.55 & 16 & 13.88 & 17.37 & 0.54 & 21.24 \\
\hline Hemp dust & 6.70 & 5.75 & 12.30 & 432 & 76.54 & 2.14 & 18 & 19.21 & 25.10 & 0.70 & 32.61 \\
\hline Shell rice & 6.85 & 1.36 & 11.10 & 109 & 87.95 & 0.62 & 71 & 29.21 & 33.21 & 0.24 & 38.00 \\
\hline Straw barley & 6.25 & 1.85 & 51.23 & n.d. & 94.03 & 0.42 & 112 & 16.91 & 17.98 & 0.10 & 23.96 \\
\hline Straw wheat & 6.37 & 2.40 & 21.19 & n.d. & 93.35 & 0.31 & 151 & 19.22 & 20.59 & 0.12 & 37.57 \\
\hline Pine bark & 7.03 & 0.48 & 37.24 & 18 & 91.75 & 0.30 & 153 & 54.68 & 59.60 & 0.14 & 45.04 \\
\hline Grass W & 6.05 & 3.32 & 63.91 & 353 & 87.26 & 2.23 & 20 & 16.41 & 18.80 & 0.38 & 17.11 \\
\hline Vegetal W & 6.67 & 2.08 & 28.17 & 160 & 84.78 & 1.1 & 39 & 27.84 & 33.15 & 0.50 & 44.51 \\
\hline OFMSW SC & 5.26 & 3.43 & 70.84 & 808 & 85.15 & 2.65 & 16 & 13.91 & 16.21 & 0.32 & 12.99 \\
\hline OFMSW MS & 5.66 & 4.90 & 48.96 & 609 & 71.17 & 1.82 & 20 & 12.55 & 18.60 & 0.28 & 17.60 \\
\hline D MSW 031 & 8.22 & 4.01 & 70.69 & 6223 & 62.25 & 4.92 & 6 & 25.36 & 40.74 & 0.80 & 16.35 \\
\hline D MSW 158 & 8.50 & 5.08 & 51.28 & 4415 & 54.54 & 1.38 & 20 & 21.60 & 39.61 & 0.46 & 33.13 \\
\hline D MSW 442 & 8.13 & 6.19 & 65.92 & 7149 & 47.14 & 1.46 & 16 & 19.15 & 40.61 & 0.49 & 33.59 \\
\hline D MSW 134 & 8.92 & 3.50 & 65.82 & 4090 & 55.24 & 3.71 & 7 & 20.84 & 37.72 & 0.91 & 24.53 \\
\hline SS 1 & 7.24 & 4.60 & 30.95 & 1955 & 49.00 & 2.70 & 9 & 17.64 & 36.01 & 0.80 & 29.66 \\
\hline SS 2 & 8.20 & 1.11 & 78.56 & 2061 & 61.01 & 4.37 & 7 & 22.45 & 36.81 & 0.82 & 18.76 \\
\hline SS 3 & 5.70 & 3.58 & 78.27 & 9532 & 83.8 & 4.60 & 9 & 34.58 & 41.27 & 0.78 & 17.00 \\
\hline $\begin{array}{l}\text { SS thermal } \\
\text { treated }\end{array}$ & 6.10 & 1.24 & 5.80 & 277 & 74.99 & 3.88 & 10 & 35.06 & 46.76 & 0.66 & 31.89 \\
\hline $\begin{array}{l}\text { Beer industry } \\
\text { SS }\end{array}$ & 6.85 & 0.75 & 89.95 & 1325 & 68.04 & 9.04 & 4 & 10.45 & 15.37 & 0.84 & 9.29 \\
\hline $\begin{array}{l}\text { Meat processing } \\
\text { W }\end{array}$ & 6.70 & 5.03 & 82.43 & 21231 & 74.76 & 6.00 & 6 & 29.38 & 39.3 & 1.56 & 26.00 \\
\hline Cow Manure & 8.95 & 7.64 & 67.11 & 525 & 57.27 & 2.55 & 11 & 20.37 & 45.55 & 0.93 & 36.00 \\
\hline PSTD & 7.10 & 36.00 & 6.21 & 962 & 62.59 & 2.32 & 13 & 28.56 & 45.62 & 0.74 & 31.89 \\
\hline Cow hair & 6.00 & 41.70 & 29.7 & n.m. & 83.3 & 9.30 & 4 & 52.50 & 63.00 & 6.70 & 72.04 \\
\hline $\begin{array}{l}\text { Treated cow } \\
\text { hair }\end{array}$ & 7.00 & 4.60 & 28.4 & n.m. & 87.6 & 14.60 & 3 & 26.30 & 30.00 & 3.20 & 21.92 \\
\hline Mean & 6.84 & 6.64 & 46.61 & 3018 & 74.91 & 3.50 & 30 & 25.10 & 34.99 & 1.00 & 30.74 \\
\hline Min & 5.26 & 0.37 & 5.80 & 18 & 47.14 & 0.30 & 3 & 5.31 & 15.37 & 0.10 & 9.29 \\
\hline Max & 8.95 & 41.70 & 89.95 & 21231 & 99.42 & 14.60 & 153 & 55.53 & 63.00 & 6.70 & 75.80 \\
\hline
\end{tabular}

W: waste; OFMSW: organic fraction of municipal solid waste; SC: separate collection; MS: mechanical separation; D: digestate; SS: Sewage sludge; PSTD: pig slurry thermally dried n.m.: non measured; n.d.: non detected

Only three samples (coffee $\mathrm{W}$, pine bark and cow hair) show the SD and rN above the proposed level (50\%) even before treatment. This behaviour could be attributed to the high lignin and other recalcitrant component compounds of bark and coffee waste and to the low degradability of the fibrilar proteins (scleroproteins) of cow hair.

Each characteristic shown for the different raw materials in table 2 is informative and can be useful as long as a proper interpretation is provided, taking into account the different origin. 
Table 3 Characteristics of three different groups of municipal solid waste composts

\begin{tabular}{|c|c|c|c|c|c|c|c|c|c|c|}
\hline & & \multicolumn{3}{|c|}{ SC, $n=167$} & \multicolumn{3}{|c|}{$M S 2, n=48$} & \multicolumn{3}{|c|}{$M S 1, n=49$} \\
\hline & & Mean & SE & Median & Mean & SE & Median & Mean & SE & Median \\
\hline Moisture & $\%$ & $26.42 b$ & 0.63 & 25.78 & $27.29 b$ & 1.39 & 27.08 & $40.08 a$ & 1.49 & 42.00 \\
\hline pH & & $8.06 a$ & 0.05 & 8.20 & $7.50 \mathrm{~b}$ & 0.08 & 7.55 & $7.14 \mathrm{c}$ & 0.10 & 7.30 \\
\hline EC & $\mathrm{dS} \mathrm{m}^{-1}$ & $7.54 b$ & 0.19 & 7.60 & $9.20 \mathrm{a}$ & 0.22 & 9.10 & $9.50 a$ & 0.21 & 9.30 \\
\hline $\mathrm{NH}_{4}{ }^{+}-\mathrm{N}$ & $\mathrm{mg} \mathrm{kg}^{-1}$ & $1013 \mathrm{c}$ & 61 & 818 & $2078 b$ & 147 & 2066 & $2944 a$ & 174 & 2673 \\
\hline CN & & $13.31 \mathrm{c}$ & 0.22 & 12.90 & $17.18 b$ & 0.40 & 16.65 & $20.09 a$ & 0.86 & 20.30 \\
\hline
\end{tabular}

Note: means in a row labelled with the same letter do not differ significantly at a $5 \%$ probability level.

\subsection{Different groups of municipal solid waste compost}

It is important to discuss the meaning of the $\mathrm{SD}$ and $\mathrm{rN}$ parameters and their connection with general characteristics as well as their relationship with organic matter stability on compost samples. In table 3 and figure 3 the general and organic matter related characteristics of compost samples are shown. All these samples have been collected representatively from composting plants at the stage where they would be considered ready for use. Consequently, all parameters studied have been subjected to changes relating to the composting treatment; each of the values is the result of the evolution of the processes (Tognetti et al., 2007).

Samples from groups SC and MS2 belong to the same period but have differences in the initial material (López et al., 2010a), because SC comes from source sorted collection and MS2 from mechanical sorting in the composting plant; apart from this, SC installations realise the co-composting of OF with yard trimmings (López et al., 2010b) and have a smaller capacity $\left(\mathrm{t} \mathrm{year}^{-1}\right)$ than MS ones, which makes control of the facility easier. The MS1 samples belong to a previous period that also treated OF from mechanical sorting at facilities but through less mechanised installations.

In this article the differences related to the contaminant levels are not considered although they are important to the final compost quality.

General characteristics show differences between the three compost groups. Moisture content is far higher in older samples (MS1), which can be attributed to poor management control in plants and fewer technologic systems to handle large quantities of material; but, moreover it can also be owed to the lack of concern over moisture, due to the lack of a densimetric table in earlier facilities. The removal of small particles of glass and gravel is a common element of modern facilities, but brings with it the handicap of needing low water content for best performance. Moisture in SC and MS2 can be considered too low, being below the current Spanish regulation (RD 824/2005), which limits content to the interval of $30-40 \%$.

The three groups have $\mathrm{pH}$ levels statically different. In the samples of SC compost the higher value is observed in well oxygenated and not yet nitrified compost (Michel and Reddy, 1998).

Electric conductivity is high in the three groups of composts because it is a characteristic of materials such as $\mathrm{OF}$, that undergo a strong degradation during composting. Nevertheless, this value could be higher if the processes were not well managed and the ammonium content is still high at the end of the process or if the initial material contains high amounts of non compostable materials. These could be the reasons for the differences between groups.

The statistical differences in the ammonium levels are favourable to the SC group that shows the lowest content. A better management and the fact that OF is co-composted with yard trimmings, can lead to the lower EC and $\mathrm{NH}_{4}{ }^{+} \mathrm{N}$ in SC samples.

In a correct composting process, TOM must diminish, relatively and absolutely, and org-N should be relatively increased. The TOM differences between groups are not clear enough owing to the OF initial difference (López et al., 2010a). The org $\mathrm{N}$ content is statistically higher in SC compost due to the initial OF composition as well as the 
better management in co-composting with $\mathrm{YT}$ in order to achieve $\mathrm{N}$ conservation. According to the results commented upon, the compost SC group shows the better results for $\mathrm{pH}, \mathrm{EC}, \mathrm{NH}_{4}{ }^{+}-\mathrm{N}$ and org- $\mathrm{N}$ and the group MS2 also shows improvements in relation to MS1 group (significantly for $\mathrm{pH}$ and $\mathrm{NH}_{4}{ }^{+}-\mathrm{N}$ ).

Characterisation of organic matter shows ROM content higher in SC reporting a higher and statistically different SD, which means that even SC has a higher TOM content, it has been more stabilised during the process. Comparing both MS1 and MS2, the latter accounts for the better results concerning stability parameters which can be attributed to an improvement in the composting process development over the years. Composting facilities that only treat organic fraction from source separate collection mixed with YT achieve higher ROM and SD values, even though they cannot be considered good enough, because SD is lower than $50 \%$.

The parameters, $\mathrm{nH}-\mathrm{N}$ and $\mathrm{rN}$, related with $\mathrm{N}$ stability shows higher values in $\mathrm{SC}$ due to the better managed process and the use of YT that provide nitrogen fixation in the carbonaceous structures. In general, yard/kitchen waste (organic fraction) yields more humic-like substances than other organic raw materials (e.g. sewage sludge). The higher content of aromatic compounds in plant materials might be the reason. Former investigations showed that humic acid formation during composting is the outcome of a well-balanced mixture of organic compounds, microbial activity, and moderate aeration (Smidt et al., 2004).

In $\mathrm{SC}$ samples $55 \%$ of org- $\mathrm{N}$ is resistant (from $\mathrm{rN}$ values) which means that this $\mathrm{N}$ form is a considerable longterm reserve of $\mathrm{N}$ while the other $45 \%$ could easily be transformed in short-medium term. In low input production systems, the presence of this slow-release $\mathrm{N}$ may be of great interest because it could contribute to maintaining optimum yields of subsequent crops if it can be mineralised at appropriate rates, and could also lead to reduce $\mathrm{N}$ losses by leaching, denitrification or volatilisation.

The calculated ratios between $\mathrm{NH}_{4}{ }^{+}-\mathrm{N}$ and org- $\mathrm{N}$ and $\mathrm{nH}-\mathrm{N}$ show statistical differences for the three groups and give interesting information for the qualification of the compost samples and its possible agronomic application.

\section{$\underline{\text { Relationship of stability degree with other parameters }}$}

Pearson correlation coefficient and its significance have been calculated for all parameters with respect to its relationship with SD (table 4). This analysis has been carried out taking into account all samples together and separately, depending on origin (SC, MS1 and MS2).

Table 4 Study of the SD correlations with other compost quality parameters

\begin{tabular}{|c|c|c|c|c|c|c|c|c|c|c|c|c|c|c|c|}
\hline & MC & pH & EC & NNH4 & TOM & ROM & DOM & $\operatorname{orgN}$ & nhN & hN & $\mathbf{r N}$ & CN & mNoN & $\mathbf{m N h N}$ & $\mathrm{SD} / \mathrm{rN}$ \\
\hline \multicolumn{16}{|c|}{ ALL, $n=264$} \\
\hline $\mathbf{r}$ & -0.305 & 0.547 & -0.485 & -0.575 & -0.234 & 0.768 & -0.738 & 0.512 & 0.702 & -0.083 & 0.654 & -0.630 & -0.664 & -0.564 & 0.251 \\
\hline$\alpha$ & $<.0001$ & $<.0001$ & $<.0001$ & $<.0001$ & 0.0001 & $<.0001$ & $<.0001$ & $<.0001$ & $<.0001$ & 0.1821 & $<.0001$ & $<.0001$ & $<.0001$ & $<.0001$ & $<.0001$ \\
\hline \multicolumn{16}{|c|}{ SC, $n=167$} \\
\hline $\mathbf{r}$ & 0.176 & 0.265 & -0.540 & -0.503 & -0.358 & 0.533 & -0.749 & 0.049 & 0.347 & -0.263 & 0.407 & -0.317 & -0.534 & -0.444 & 0.298 \\
\hline$\alpha$ & 0.0231 & 0.0006 & $<.0001$ & $<.0001$ & $<.0001$ & $<.0001$ & $<.0001$ & 0.5289 & $<.0001$ & 0.0006 & $<.0001$ & $<.0001$ & $<.0001$ & $<.0001$ & $<.0001$ \\
\hline \multicolumn{16}{|c|}{$M S 2, n=48$} \\
\hline $\mathbf{r}$ & 0,115 & 0,281 & $-0,298$ & $-0,215$ & $-0,440$ & 0,008 & $-0,610$ & $-0,177$ & 0,106 & $-0,246$ & 0,304 & $-0,334$ & $-0,146$ & $-0,109$ & 0,188 \\
\hline$\alpha$ & 0.4353 & 0.0527 & 0.0400 & 0.1471 & 0.0018 & 0.9578 & $<.0001$ & 0.2277 & 0.4747 & 0.0921 & 0.0358 & 0.0203 & 0.3272 & 0.4667 & 0.2005 \\
\hline \multicolumn{16}{|c|}{$M S 1, n=49$} \\
\hline $\mathbf{r}$ & $-0,416$ & 0,357 & 0,426 & 0,524 & $-0,564$ & 0,459 & $-0,743$ & 0,039 & 0,213 & $-0,050$ & 0,170 & $-0,424$ & 0,411 & 0,448 & 0,517 \\
\hline$\alpha$ & 0.0029 & 0.0118 & 0.0023 & 0.0001 & $<.0001$ & 0.0009 & $<.0001$ & 0.7889 & 0.1456 & 0.7351 & 0.2483 & 0.0041 & 0.0034 & 0.0014 & 0.0002 \\
\hline
\end{tabular}


The SD of all compost samples and the SC group shows significant and positive correlations with $\mathrm{pH}$, org- $\mathrm{N}$, $\mathrm{rN}$ and negative correlations with $\mathrm{EC}, \mathrm{NH}_{4}{ }^{+}-\mathrm{N}$ and $\mathrm{C} / \mathrm{N}$. The more interesting and informative correlations are discussed.

Moisture content in final products shows a negative correlation with SD in most of the groups but probably the moisture level during the process would be better correlated with SD.

$\mathrm{pH}$ is significantly positively correlated with SD for all groups except for MS2. During the proper composting process there is an increase in $\mathrm{pH}$ due to a faster decomposition of the acids formed in the former stages of the process, to the release of ammonia from microbial protein degradation, and to the possibility of bicarbonate and carbonate formation (Tognetti et al., 2007). Only when the last maturation phase is longer and adequate conditions for nitrification are kept, can the $\mathrm{pH}$ drop.

Electric conductivity is negatively and statistically correlated with SD except for MS1 which shows a positive correlation. Ammonium is significantly negatively correlated for complete data sets and the SC group. The expected relationship would be that as the more stable the compost becomes the lower the ammonium content; in case of MS1, SD is the lowest of the three groups (fig 3) and accounts for the higher ammonium content, usually detected in low quality composts.

Not all groups show the same correlations because the factors affecting these parameters can be different in each situation described. Probably, the EC values in SC and MS2 groups are more affected by moisture and ammonium content, while in the MS1 group the initial waste stream components can be responsible for the result obtained. Likewise, ammonium content in SC samples might be more related to the transformation pattern of the material during the process than in MS samples.

Total and degradable organic matter are negatively correlated with SD in all groups, fitting in with the fact that during the composting process the TOM and mainly de DOM reduces while the organic matter stabilisation increases.

Nitrogen shows different behaviour depending on the kind and group of sample. Organic nitrogen only shows a significant positive correlation when all samples are considered together and with SC group; the correlation with $\mathrm{nH}-\mathrm{N}$ is significant and positive for the complete data set and the SC group. Finally, $\mathrm{rN}$ shows a significant positive correlation except for MS1.

$\mathrm{C} / \mathrm{N}$ rate is considered by some authors as an indicator of maturity (Bernal et al., 1998) and is expected to decrease during the process. So, as has been found, it is negatively correlated with SD for all groups.

\subsection{Different groups of SC compost according stability degree}

Despite SC compost samples showing better general results and stability parameters (table 4) than those in MS, observations must be made because the mean does not reach the advised values ( $50 \%$ for SD and $\mathrm{rN}$ ) or very low values appear in some individual results. If SC samples are split into groups depending on SD values probably the results of other parameters could be correlated among them and related to the quality of management. Three groups of samples were established: SC1, SC2 and SC3, according to the SD level: SD $\geq 50,50>S D \geq 43$ and $43>$ SD respectively. The results of this classification (table 5 and figure 4) agree with the subjective evaluation of compost properties such as odour, colour, texture and particle size, and also with the assessment forecast in their compost management system during previous visits for sampling.

Table 5 Characteristics of SC compost samples according to stability degree

\begin{tabular}{|c|c|c|c|c|c|c|c|c|c|c|}
\hline & & \multicolumn{3}{|c|}{$\mathrm{SC} 1, \mathrm{n}=53$} & \multicolumn{3}{|c|}{$\mathrm{SC} 2, \mathrm{n}=65$} & \multicolumn{3}{|c|}{$\mathrm{SC} 3, \mathrm{n}=49$} \\
\hline & & Mean & SE & Median & Mean & SE & Median & Mean & SE & Median \\
\hline Moisture & $\%$ & $28.65 a$ & 1.19 & 28.68 & $25.78 a$ & 0.91 & 25.09 & $24.85 a$ & 1.16 & 23.20 \\
\hline pH & & $8.29 a$ & 0.07 & 8.35 & 8.04ab & 0.07 & 8.20 & $7.84 b$ & 0.11 & 7.90 \\
\hline EC & $\mathrm{dS} \mathrm{m}^{-1}$ & $5.86 \mathrm{c}$ & 0.30 & 5.85 & $7.81 b$ & 0.27 & 7.60 & $8.98 a$ & 0.32 & 9.05 \\
\hline $\mathrm{NH}_{4}{ }^{+}-\mathrm{N}$ & $\mathrm{mg} \mathrm{kg}^{-1}$ & $584.33 c$ & 69.47 & 509.00 & 957.09b & 59.06 & 926.00 & $1543.15 a$ & 145.92 & 1102.50 \\
\hline $\mathrm{CN}$ & & $12.60 a$ & 0.44 & 11.90 & $13.00 a$ & 0.30 & 13.00 & $14.50 \mathrm{~b}$ & 0.40 & 14.60 \\
\hline
\end{tabular}

Note: means in a row labelled with the same letter do not differ significantly at a $5 \%$ probability level. 
Moisture content is low and no different between groups and it must be improved. There are statistical differences for parameters such as $\mathrm{pH}, \mathrm{EC}$ and $\mathrm{NH}_{4}{ }^{+}-\mathrm{N}$; the group SC1 with highest SD values shows the highest $\mathrm{pH}$ and the lowest values for $\mathrm{EC}$ and $\mathrm{NH}_{4}{ }^{+}-\mathrm{N}$ level, which corresponds to a better process management and a better compost quality. The $\mathrm{NH}_{4}{ }^{+}-\mathrm{N}$ content can be relevant to the process management, being a consequence of it, in which variables like temperature, aeration, $\mathrm{pH}$ and moisture can affect the result (Bernal et al., 2009). Taking into account the values obtained after splitting SC into three groups, in which the differences in the process (aeration, temperature...) among different facilities can be extreme, and consequently between groups, it has also been observed that the relationship between $\mathrm{SD}$ and $\mathrm{NH}_{4}{ }^{+}-\mathrm{N}$ has been maintained.

The highest value of TOM is found in SC3, indicating a poor reduction during the process. Dry matter losses, mainly due to organic matter mineralisation, are highest in SC1, showing that the conditions to improve microbial activity and consequently the conditions for biodegradation (moisture, oxygen, nutrient balance) have been better monitored.

With respect to levels of nitrogen, the organic is different from SC2 to SC3 while SC1 is statistically identical to both. Instead, $\mathrm{nH}-\mathrm{N}$ is lower and different for SC3. The $\mathrm{C} / \mathrm{N}$ ratio is highest in SC3, which confirms that lower OM degradation has taken place.

\section{Conclusions}

Composting can be a reliable technology to achieve some specific goals with organic waste, changing it from an environmental nuisance to a useful product, or one that is easy to dispose of.

\section{About SD method:}

- $\quad$ The stability degree presented in this article is useful to evaluate the stability of compost samples and any EOM, assessing if stability treatment is needed before use, besides giving information on the short and longterm supply of $\mathrm{N}$. It can help to predict the behaviour of the treated material when it has to be land applied or land filled.

- $\quad$ SD is a useful method to determine the stability because it is not affected by certain sample conditions such as temperature, water content, particle size, etc., as observed in respirometric techniques or self-heating test. This can mainly be interesting in EOM that are directly applied to soil but in which other analytical methodologies cannot fit properly. Because SD is applied to dry and milled sample, homogeneity and representativity are improved and good results can be obtained from all kinds of material analysed. On the other hand, to obtain representative results, despite good homogeneity of the samples, a strict application of the methodology is necessary throughout the process due to the particular steps required.

- $\quad$ The SD and Nr values are useful to infer the decomposition and mineralisation rates in soil and the potential release of available $\mathrm{N}$ from any compost, which could help growers/farmers make appropriate decisions about compost use. In relation to compost producers, monitoring the stability can inform about the composting process development.

- $\quad$ Taking into account the correlation of SD with parameters such as EC, C/N or ammonium, which are considered indicators of maturity, SD can then be considered as a reliable method to assess maturity.

\section{About the comparison of different materials analysed:}

- The organic raw materials studied show great heterogeneity of the characteristics studied, even SD and rN, although the information obtained is important to decide on the disposal and/or use. The results are consistent for all of the materials tested, taking into account their origin and presumed biomolecular composition and treatment.

- $\quad$ Compost samples studied showed different SD and rN levels according to origin. SD is higher in SC compost than MS, and inside the former group samples can be sorted by quality from SD values. The group with highest SD presents results in accordance with the lowest values of ammonium, TOM and EC and higher pH. 
- The results obtained confirm the suitability of this method for the study of the biological stability of compost and bio stabilised raw organic wastes, as well as the importance of SD and $\mathrm{rN}$ to evaluate the composting process and product quality, which must not be overlooked.

- Each method of waste characterisation is developed for a specific purpose; SD method is a descriptive index with the ability to indicate the biodegradability of organic materials, which it can be useful to obtain information about:

- the need to stabilise some organic raw wastes before applying them to soil

- the completion of the composting process

- the stability of composts from any origin regardless of specific characteristics such as moisture content, particle size, etc.

- the behaviour on soil application

- the acceptance criteria for landfill

Interpretation and application of SD and $\mathrm{rN}$ results requires the understanding of the composting process, the feedstock included, and the scientific fundamentals involved.

\section{Acknowledgments}

The authors acknowledge financial and/or technical support to SERVEI DE MEDI AMBIENT DE LA DIPUTACIÓ DE BARCELONA, MINISTERIO DE MEDIO AMBIENTE, AGĖNCIA DE RESIDUS DE CATALUNYA.

\section{References}

Adani F, Genevini PL, Tambone F. A new index for compost stability. Compost Sci Util 1995; 3:25-37.

Adani F, Ricca G. The contribution of alkali soluble (humic acid-like) and unhydrolyzed-alkali soluble (core-humic acid-like) fractions extracted from maize plant to the formation of soil humic acid. Chemosphere 2004; 56:13-22.

Adani F, Tambone F, Genevini P. Effect of compost application rate on carbon degradation and retention in soils. Waste Manage 2009; 29:174-179.

Bernal MP, Navarro AF, Sánchez-Monedero MA, Roig A, Cegarra J. Influence of sewage sludge compost stability and maturity on carbon and nitrogen mineralization in soil. Soil Biol Biochem 1998; 30:305-313.

Bernal MP, Alburquerque JA, Moral R. Composting of animal manures and chemical criteria for compost maturity assessment. A review. Bioresource Technol 2009; 100:5444-5453.

Binner $E$, Zach A. Biological reactivity of residual wastes and dependence on the duration of pre-treatment. Waste Manage Res 1999; 17:543-554.

Biocyle's Editor. Reader's Q and A. In: BioCycle, Editor, The BioCycle Guide to the Art and Science of Composting, JG Press, Emmaus, USA. February, 1999; pp. 18-19.

Busche R. The Klason lignin determination as applied to aspenwood with special reference to acid-soluble lignin. Dissertation. Lawrence College. Appleton, Winsconsin; 1960.

Cooperband LR, Stone AG, Fryda MR, Ravet JL. Relating compost measures of stability and maturity to plant growth. Compost Sci Util 2003; 11:13-124.

Favoino E, Hogg D. The potential role of compost in reducing greenhouse gases. Waste Manage Res 2008; 26:61-69.

Giovannozzi-Sermanni C. Lignin Metabolism in the Soil Amended with Compost. In: Bertoldi M, Ferranti MP, I'Hermite P, Zucconi F (Eds.) Compost: production, quality and use. Elsevier Applied Science; 1987. p. 190-197.

Hammouda GNH, Adams WA. The decomposition, humification and fate of nitrogen during the composting of some plant residues. In: Bertoldi M, Ferranti MP, I'Hermite P, Zucconi F (Eds.). Compost: production, quality and use. Elsevier Applied Science; 1987. p. 239-245.

Higgins AJ, Kapovsky AJ, Huntes JV. Organic composition of aerobic, anaerobic and compost stabilized sludges. J Water Poll Control Fed 1982; 54:466-473.

Hutchinson M, Griffin I. Evaluation of Fiber Content Relative to Other Measures of Compost Stability. Compost Sci Util 2008; 16:6-11.

Inoko A, Miyamatsu K, Sugahara K, Harada Y. Some organic constituents of city refuse compost produced in Japan. Soil Sci Plant Nutr 1979; 25:225-234. 
Klason P. 1908. Ber. Hauptversammlung des Vereins der Zellstoff-und Papierchemiker 53. In: Hussain MA, Huq ME, Rahman SM, Ahmed Z. Estimation of lignin in jute by titration method. Pakistan J Biol Sci 2002; 5:521-522.

Klason P. 1910. Determining of lignin in sulphite wood pulp. Papierfabr 8:1285-6. In: Hussain MA, Huq ME, Rahman SM, Ahmed Z. Estimation of lignin in jute by titration method. Pakistan J Biol Sci 2002; 5:521-522.

Lay JJ, Li YL, Noike T, Endo J, Ishimoto S. Analysis of environmental-factors affecting methane production from high-solid organic waste. Water Sci Technol 1997; 36:493-500.

López M, Soliva M, Martínez-Farré FX, Fernández M, Huerta-Pujol O. Evaluation of MSW organic fraction for composting: Separate collection or mechanical sorting. Resour Conserv Recy 2010a; 54(4):222-228.

López M, Soliva M, Martínez-Farré FX, Bonmatí A, Huerta-Pujol O. An assessment of the characteristics of yard trimmings and recirculated yard trimmings used in biowaste composting. Bioresource Technol 2010b; 101(4):1399-1405.

López M. Determinació i avaluació de l'estabilitat i maduresa de material orgànics i de compost (Determination and evaluation of stability and maturity of organic materials and compost). Dissertation. Politecnical University of Catalonia. 2010; 266pp.

Michel FC, Reddy CA. Effect of oxygenation level on yard trimmings composting rate, odor production, and compost quality in bench-scale reactors. Compost Sci Util 1998; 6:6-14.

Mikutta R, Kleber M, Torn MS, Jahn R. Stabilization of soil organic matter: association with minerals or chemical recalcitrance? Biogeochemistry 2006; 77:25-56.

Ministère de l'Agriculture de Belgique. Convention pour l'Anslyses des engrais et des Amendements du Sol. Part II, pp. 202-203. Div.B.Ad. Services Economiques d'Inspection de matières Premièrers. 1971.

Moré JC, Saña J. Criteria of quality of city refuse compost base don the stability of its organic fraction. In: de Bertoldi M, Ferranti MP, L'Hermite P, Zucconi F (Eds) Compost: Production, Quality and Use. Elsevier Applied Science. London; 1987. pp 309-320.

Morvan T, Nicolardot B. Role of organic fractions on $\mathrm{C}$ decomposition and $\mathrm{N}$ mineralization of animal wastes in soil. Biol Fertil Soils 2009; 45:477-486.

NREL (National Renewable Energy Laboratory). TAPPI Test Method T222 om-88. Acid-Insoluble Lignin in Wood and Pulp. Technical Association of the pulp and paper industry; 2002. 13p.

Rovira P, Vallejo VR. Labile and recalcitrant pools of carbon and nitrogen in organic matter decomposing at different depths in soil: an acid hydrolysis approach. Geoderma 2002; 107:109-141.

Saña J. La utilització dels fangs de depuradores d'aigües residuals urbanes com a adobs: caracterització de la seva fracció orgànica. (Utilization of urban sewage sludge as fertiliser: characterization of its organic fraction). Dissertation. Facultat de Farmàcia. Universitat de Barcelona. 1985.

Saña J, Giró F, Soliva M, Florensa P. Methodology used for evaluating the quality of compost produced in Catalonia. In: Simposio internazionale produzione ed impiego del compost, 20-23 june 1989, S. Michele All'Adige, Italy; 1989. pp. 343-362.

Sjöström E, Alén R. Analytical methods in wood chemistry, pulping, and papermaking. Springer Series in Wood Science. Ed. Berlin: Springer-Verlag; 1999. 316pp.

Smidt E, Binner E, Lechner P. Humic acid formation in composts-the role of microbial activity. In: Verstraete W (Ed.) Proceedings of the European Symposium on Environmental Biotechnology ESEB 2004, Oostende, Belgium; 2004. pp. 143-146.

Smith P. Carbon sequestration in croplands: the potential in Europe and the global context. Europ J Agron 2004; 20:229-236.

Sullivan DM, Bary AI, Nartea TJ, Myrhe EA, Cogger CG, Fransen SC. Nitrogen availability seven years after a high-rate food waste compost application. Compost Sci Util 2003; 11:265-275.

Tognetti C, Mazzarino MJ, Laos F. Improving the quality of municipal organic waste compost. Bioresource Technol 2007; 98:1067-1076.

Tomati U, Madejon E, Galli E. Evolution of humic acid molecular weight as an index of compost stability. Compost Sci Util 2000; 8:108-115.

Tuomela M, Vikman M, Hatakka A, Itavaara M. Biodegradation of lignin in a compost environment: a review. Bioresource Technol 2000; 72:169-183.

Van Soest PJ, Wine RH. Use of detergents in the analysis of fibrous feeds. IV. Determination of cell-wall constituents. Journal of the Association of Analytical Chemistry 1967; 50:50-55

Veeken AHM, Adani F, Nierop KGJ, de Jager PA, Hamelers HVM. Degradation of Biomacromolecules during High-Rate Composting of Wheat Straw-Amended Feces. J Environ Qual 2001; 30:1675-1684.

von Post L. Das Genetische System der Organogenen Bildungen Schwedens (Genetic Classification for the Organic Soils of Sweden). Comité Intemational de Pédologie IV, Communication, 1924; 22:287-304 (in German).

Wagland ST, Tyrrel SF, Godley AR, Smith R. Test methods to aid in the evaluation of the diversion of biodegradable municipal waste (BMW) from landfill. Waste Manage 2009; 29:1218-1226.

Wu L, Ma LQ. Effects of sample storage on biosolids compost stability and maturity evaluation. J Environ Qual 2001; 30:222228. 